\title{
The Cognitive Science of Religion: WHEREFROM, WHERETO?
}

\author{
Armin W. Geertz, Valerie van Mulukom, \\ Kristoffer LaigaArd Nielbo
}

Aarhus University; Coventry University; Aarhus University

awg@cas.au.dk; ac2492@coventry.ac.uk; kln@cas.au.dk

Please join us in celebrating the first five volumes of the Journal for the Cognitive Science of Religion (JCSR) with this special issue on cognitive approaches to religion and imagination, edited by Valerie van Mulukom.

If there is anything that we have learned about the cognitive science of religion during the past several years, it is that the CSR is continually changing and developing. Arising from the pioneering efforts of first-generation CSR scholars who paved the way for the rest of us, we are confronted today with a highly creative explosion of studies that are either directly published by CSR scholars or by colleagues from other disciplines who have contributed to our field. Furthermore, the theories, hypotheses and empirical results of CSR research have inspired scholars in psychology, the humanities, biology and even the medical sciences. New methodological tools have become more prominent these past few years changing the way we work, such as data-intensive techniques like data mining, machine learning, neural networks and computer simulations. Our results are becoming more precise, as well as more generalizable.

The first four volumes of the JCSR give a good indication of the challenges, issues and perspectives of contemporary CSR research. Already in the first issue (1.1, June 2013), the variety of CSR approaches was highlighted with articles on the results of experimental studies of first-generation hypotheses and theories (Pyysiäinen 2013), how religious rituals affect social belonging (Sibley and Bulbulia 2013), the new field of normative cognition (Jensen 2013), the application of cognitive resource depletion theory on ritual (Nielbo et al. 2013) and the cognitive ecology of religious concepts (Purzycki 2013). The second issue (1.2, December 2013) highlighted the variety of experimental approaches to the cognitive science of religion, from its importance for the humanities (Bulbulia 2013; Sørensen and Nielbo 2013) to computer modeling (Lane 2013) and analyses of MCI theory and Terror Management Theory (Jong 2013; Porubanova-Norquist et al. 2013). Since then, the Journal for the Cognitive Science of Religion has published research 
on a variety of themes such as priming and supernatural agency (Nieuwboer et al. 2014), sensory processing and suppression in spiritual experiences (van Elk 2014), atheism (Talbot and Wastell 2015), reputation management (Nordin 2015) and attitudes towards state-sanctioned punishment (O'Lone and McKay 2016). The journal has published data on a number of different religions such as ancient Greek and Roman religions (Ambasciano 2015, 2016), religion in Medieval India (Chilcott 2015), among the Tyva (Purzycki 2013), among Christians in New Zealand (Sibley and Bulbulia 2013) and in the Greek Catholic Church in Western Ukraine (Halemba 2016; TalmontKaminski 2016). Furthermore, we have devoted three issues of target articles with peer responses on central CSR debates, namely, religion and prosociality (2.1, June 2014; Martin and Wiebe 2014), philosophy and the cognitive science of religion (3.1, June 2015; Gardiner and Engler 2015) and evolutionary theories of religion (4.1, June 2016; Turner 2016).

In sum, CSR can be characterized as a comparative, cross-cultural, multidisciplinary, multimodal, historical and evolutionary science. CSR consists of scholars who are theoretically and methodologically precise in pursuance of empirical studies of religious ideas and behaviors. CSR scholars are also pushing the boundaries of our understanding of cognition. Both top-down and bottom-up approaches are customary, often within the same studies. The cognitive science of religion is paving the way for new explanations of religion. Indeed, CSR has changed the way we view the world and how we analyze it.

In this issue, edited by Valerie van Mulukom, we have chosen a topic that is understudied in the cognitive science of religion. Religion and imagination would seem to be a central topic to the cognitive science of religion, but little has been published on it in CSR journals. Valerie van Mulukom presents a first appraisal of the field in her introduction. The introduction also explains and contextualizes the contributions by cutting-edge scholars in this field of inquiry.

We hope that you will enjoy this issue. Future issues will also deal with topics crucial to CSR scholarship which we hope will be well-received by colleagues (please see our calls for papers at the journal website).

\section{References}

Ambasciano, Leonardo. 2015. "Mapping Pluto's Republic: Cognitive and Epistemological Reflections on Philosophy of Pseudoscience: Reconsidering the Demarcation Problem." Journal for the Cognitive Science of Religion 3: 18-205.

. 2016. "Wine, Brains, and Snakes: An Ancient Roman Cult between Gendered Contaminants, Sexuality, and Pollution Beliefs." Journal for the Cognitive Science of Religion 4: 123-154. 
Bulbulia, Joseph. 2013. "The Arts Transform the Cognitive Science of Religion." Journal for the Cognitive Science of Religion 1: 141-160.

Chilcott, Travis. 2015. "Reappraising Objects of Desire through Practices of Devotion: A Cognitive Historiographical Approach to Religious Claims in Medieval India." Journal for the Cognitive Science of Religion 3: 155-181.

Gardiner, Mark Q. and Steven Engler. 2015. "The Philosophy and Semantics of the Cognitive Science of Religion.” Journal for the Cognitive Science of Religion 3: 7-35.

Halemba, Agnieszka. 2016. "Response to Konrad Talmont-Kaminski’s Review: Embracing Apparitions for Unity." Journal for the Cognitive Science of Religion 4: 197-209.

Jensen, Jeppe Sinding. 2013. "Normative Cognition in Culture and Religion.” Journal for the Cognitive Science of Religion 1: 47-70.

Jong, Jonathan. 2013. "On Faith and the Fear of Fatality: A Review of Recent Research on Deities and Death." Journal for the Cognitive Science of Religion 1: 193-214.

Lane, Justin E. 2013. "Method, Theory, and Multi-Agent Artificial Intelligence: Creating Computer Models of Complex Social Interaction." Journal for the Cognitive Science of Religion 1: 161-180.

Martin, Luther H. and Donald Wiebe. 2014. "Pro- and Assortative-Sociality in the Formation and Maintenance of Religious Groups." Journal for the Cognitive Science of Religion 2: 5-16.

Nielbo, Kristoffer L., Uffe Schjoedt and Jesper Sørensen. 2013. "Hierarchical Organization of Segmentation in Non-Functional Action Sequences." Journal for the Cognitive Science of Religion 1: 71-97.

Nieuwboer, Wieteke, Hein T. van Schie and Daniël Wigboldus. 2014. "Priming with Religion and Supernatural Agency Enhances the Attribution of Intentionality to Natural Phenomena." Journal for the Cognitive Science of Religion 2: 97-119.

Nordin, Andreas. 2015. "Indirect Reciprocity and Reputation Management in Religious Morality Relating to Concepts of Supernatural Agents." Journal for the Cognitive Science of Religion 3: 125-153.

O’Lone, Katherine and Ryan McKay. 2016. "Divine Forgiveness and Human Support for State-Sanctioned Punishment." Journal for the Cognitive Science of Religion 4: 155-184.

Porubanova-Norquist, Michaela, Daniel Joel Shaw and Dimitris Xygalatas. 2013. "Minimal-Counterintuitiveness Revisited: Effects of Cultural and Ontological Violations on Concept Memorability." Journal for the Cognitive Science of Religion 1: 181-192.

Purzycki, Benjamin Grant. 2013. "Toward a Cognitive Ecology of Religious Concepts: An Example from the Tyva Republic.” Journal for the Cognitive Science of Religion 1: 99-120. 
Pyysiäinen, Ilkka. 2013. "Cognitive Science of Religion: State-of-the-Art.” Journal for the Cognitive Science of Religion 1: 5-28.

Sibley, Chris G. and Joseph Bulbulia. 2013. "Healing Those Who Need Healing: How Religious Practice Interacts with Personality to Affect Social Belonging." Journal for the Cognitive Science of Religion 1: 29-45.

Sørensen, Jesper and Kristoffer L. Nielbo. 2013. "The Experimental Study of Religion: Or There and Back Again." Journal for the Cognitive Science of Religion 1: 215-232.

Talbot, Elizabeth and Colin Arthur Wastell. 2015. "Corrected by Reflection: The De-Anthropomorphized Mindset of Atheism." Journal for the Cognitive Science of Religion 3: 113-124.

Talmont-Kaminski, Konrad. 2016. "Embracing Apparitions for Unity: Agnieszka Halemba on a Marian Apparition Site." Journal for the Cognitive Science of Religion 4: 185-196.

Turner, Jonathan H. 2016. "Using Neurosociology and Evolutionary Sociology to Explain the Origin and Evolution of Religions." In Journal for the Cognitive Science of Religion, 2018 4: 7-29.

van Elk, Michiel. 2014. "An EEG Study on the Effects of Induced Spiritual Experiences on Somatosensory Processing and Sensory Suppression." Journal for the Cognitive Science of Religion 2: 121-157. 